Article

\title{
Conditions Influencing Mould Growth for Effective Prevention of Wood Deterioration Indoors
}

\author{
Edgars Kuka *, Dace Cirule $\mathbb{B}^{(}$, Ingeborga Andersone, Bruno Andersons and Velta Fridrihsone
}

Citation: Kuka, E.; Cirule, D.; Andersone, I.; Andersons, B. Fridrihsone, V. Conditions Influencing Mould Growth for Effective Prevention of Wood Deterioration Indoors. Appl. Sci. 2022 12, 975. https://doi.org/10.3390/ app12030975

Academic Editor: Emanuela Bosco

Received: 29 December 2021

Accepted: 15 January 2022

Published: 18 January 2022

Publisher's Note: MDPI stays neutral with regard to jurisdictional claims in published maps and institutional affiliations.

Copyright: (C) 2022 by the authors. Licensee MDPI, Basel, Switzerland. This article is an open access article distributed under the terms and conditions of the Creative Commons Attribution (CC BY) license (https:// creativecommons.org/licenses/by/ $4.0 /)$.
Latvian State Institute of Wood Chemistry, Dzerbenes iela 27, LV-1006 Riga, Latvia; dace.cirule@kki.lv (D.C.); i.andersone@edi.lv (I.A.); bruno.andersons@edi.lv (B.A.); velta.fridrihsone@kki.lv (V.F.)

* Correspondence: edgars.kuka@kki.lv

\begin{abstract}
Effective prevention of mould growth indoors is still an important topic considering that mould growth is frequently observed in buildings, it causes serious health hazards and can irreversibly damage infected objects. Several studies have been conducted and mould growth models developed. Despite that, some potentially important aspects such as water damage and spore contamination have received only little attention. The objective of the present study was to investigate the effect of the initial moisture content of wood and spore contamination on mould development indoors. The mould tests were performed in constant temperature $\left(10,20\right.$ and $\left.30{ }^{\circ} \mathrm{C}\right)$ and relative humidity $(91 \%$ and $97 \%$ ) conditions. The results show that wetting of wood specimens prior to the test significantly accelerates mould growth at a temperature of $10^{\circ} \mathrm{C}$. For the other temperatures, the effect was insignificant. Similar results were obtained for the test involving dry (conditioned at $\mathrm{RH} 50 \%$ ) and conditioned specimens ( $\mathrm{RH} 91 \%$ or $\mathrm{RH} 97 \%$ ). The results regarding initial spore contamination show that significantly longer periods are required for mould to develop without spore contamination at $10{ }^{\circ} \mathrm{C}$ and $20^{\circ} \mathrm{C}$, while at $30^{\circ} \mathrm{C}$ the effect is relatively small.
\end{abstract}

Keywords: mould growth; wood; temperature; relative humidity; moisture content; surface wetting; spore contamination; mould prevention

\section{Introduction}

Although mould growth in buildings is not a new problem, research into the growth conditions of these fungi is still of high topicality and importance. The quite common and repeatedly observed mould growth problems in buildings suggest that more information and deeper knowledge is required for their prevention [1]. Some of the most frequent causes of mould growth in buildings are high humidity, cold surface temperatures, wet objects, water hazards, poor air quality, etc. [2]. Due to ubiquitous viable spores, mould growth is possible in all indoor environments. This makes the complete avoidance of them impossible; however, the amount can be significantly reduced by ensuring proper air ventilation and limiting exposure to potential mould contaminators [3]. Different mould species characteristic of the indoor environment are usually found in damp and waterdamaged buildings, some of which dangerously pollute indoor air [4-6]. From a health point of view, visible mould growth is the main concern [7]. It is suggested that mycotoxins production responsible for adverse health effects in buildings occurs when water activity $\left(\mathrm{a}_{\mathrm{w}}\right)$ at the surface of the material exceeds 0.90 . However, significant toxin synthesis does not begin until $\mathrm{a}_{\mathrm{w}}$ reaches 0.95 [8]. Mycotoxic effects in indoor air can be caused by toxigenic fungal spores, their fragments and mycelium as well as products of moulds metabolisms. These toxic or harmful compounds cause the well-known immediate allergic reactions, respiratory infections and even serious illness [2,8]. It is important to note that killing fungal organisms usually does not destroy their antigenic or toxic properties. This means that even the presence of dead fungi still remains a problem long after the favourable conditions of mould growth have been eliminated [9]. Another important aspect is discolouration 
causing visible and irreversible damage to objects, which is especially important for the artefacts in heritage collections that cannot be replaced [9-12]. These circumstances have increased the public awareness of the potential risks of mould, demanding higher indoor air quality as well as searching for supporting strategies to control mould growth in homes and public spaces.

Mould growth requires proper nutrients, which are self-provided by enzymatic digestion of organic materials [13]. Due to its organic nature and hygroscopic properties, wood is highly susceptible to mould providing sufficient nutrients for spore germination and mycelium growth. Some wood species are more susceptible to mould growth than others. It is suggested that the main influencing factors are the amount and composition of wood extractives [14], differences in such physical parameters as wood moisture content as well as density between different wood species have only minor effect on mould resistance $[15,16]$. Within the same wood species, higher level of antifungal and hydrophobic wood extractives are reported as the main contributors for the enhanced mould resistance of heartwood over sapwood [17,18]. Furthermore, by analysing mould growth on various wood species, it is found that mould resistance has a positive correlation with the amount of antifungal extractives [14]. It was found that softwoods generally contained higher amounts of antifungal extractives, which resulted in higher resistance comparing to hardwoods. It has also been hypothesized that the larger content of hemicelluloses contributes to the higher mould resistance of softwoods over hardwoods [19]. On the other hand, the mould resistance of heat-treated wood is only slightly improved, despite the significantly reduced amount of hemicelluloses $[20,21]$. However, this could be attributed to the mould growth enhancing factors such as the removal of all initial antifungal extractives and the increase in the amount of monosaccharides [20,22]. In general, none of these previously mentioned factors concerning nutrients could eliminate mould growth as the nutritional requirements are usually minimal and satisfied either by the material constituents or by a minor contamination of the surface by dust or other deposit [13]. Therefore, environmental conditions-relative humidity $(\mathrm{RH})$ and temperature-and time are the limiting factors influencing mould growth. The combination of them determines the probability and the extent of the mould development. Indoors, the environmental factors can be relatively easily controlled, and prevention of persistent dampness, elimination of moisture intrusion and temporary leaks prevent mould proliferation [2]. A special situation is when wood is subjected to water disaster such as domestic accidents, floods or firefighting activities resulting in high $\mathrm{RH}$ and prolonged periods of increased moisture content. In the literature, it is intensively discussed that the RH of the ambient air cannot represent the real situation near the surface where the actual biological activity happens [7]. Therefore, in microbiology, $\mathrm{a}_{\mathrm{w}}$ is adapted, which characterises the amount of free water available to microorganisms, $\mathrm{RH}$ of the air and also the moisture content of the material [6]. The $\mathrm{a}_{\mathrm{w}}$ is undoubtedly the most important factor in determining whether or not mould growth is initiated [3]. RH (expressed as a fraction) and $\mathrm{a}_{\mathrm{w}}$ are equal in the situations when a system reaches the state of moisture equilibrium [13].

For simplicity, the RH and $\mathrm{a}_{\mathrm{w}}$ at equilibrium conditions will be both referred as equilibrium relative humidity $(\mathrm{ERH})$ and in the case of non-equilibrium conditions, the terms $\mathrm{RH}$ and $\mathrm{a}_{\mathrm{w}}$ will be used. Mould growth requires specific moisture condition. Depending on ERH and $\mathrm{a}_{\mathrm{w}}$, different outcomes are possible: no mould growth, mould germination (observed only with microscope) and visible mould growth. It has been found that the limits for each outcome are as follows: for ERH below 80\% mould cannot develop; for ERH above $80 \%$, spore germination takes place; and for ERH above $85 \%$, visible mould growth can develop $[7,23,24]$. According to other sources, mould does not grow at ERH $<75 \%$ at $20{ }^{\circ} \mathrm{C}$ [25]. It is also believed that the lower limit of $\mathrm{a}_{\mathrm{w}}$ for fungal growth on wood and wood composites is 0.78 at $20-25^{\circ} \mathrm{C}$, and the germination process requires a slightly (approx. 0.02) higher $\mathrm{a}_{\mathrm{w}}$ than the critical $\mathrm{a}_{\mathrm{w}}$ for growth [3]. The differences in the results can be explained by a different experimental design. In addition, it should be noted that 
each fungal species has a specific minimum $\mathrm{a}_{\mathrm{w}}$ to grow. Moderately xerophilic fungi begin to grow at a $a_{w}$ of $0.75-0.79$, but the minimum $a_{w}$ for hydrophilic fungi is 0.90 [26].

Indoors, the RH can significantly fluctuate. Even in such a well-controlled environments as museums, $\mathrm{RH}$ can fluctuate in relatively broad range: $10-80 \%$ [27]. It seems that the mould growth is almost impossible; however, as mentioned above, the main parameter is $\mathrm{a}_{\mathrm{w}}$, which can be much higher due to surface condensation or accidental moistening. The studies have shown that in the case of surface wetting, favourable conditions of mould growth can be maintained for a relatively long period, but it may only take a few days for a fungus to germinate and begin to grow $[7,13]$. These aspects have had only minor attention in the literature concerning wood. Water is undoubtedly the most important factor for initiation of mould growth; however, temperature also has a major effect since biochemical processes are highly dependent on the metabolic activity of mould growth [1]. The recommendations for museums as well as the real temperature monitoring data have shown that the temperature fluctuations are usually between $10-30{ }^{\circ} \mathrm{C}$ [27-29] and almost never are below $5{ }^{\circ} \mathrm{C}$ or over $53{ }^{\circ} \mathrm{C}$, which are the lower and upper limits for the fungal spore germination [30]. Therefore, for efficient mould growth prevention indoors, the critical factor is humidity, and temperature is only an accelerator. In other words, if the $\mathrm{a}_{\mathrm{w}}$ is higher than 0.8 (ERH 80\%), mould growth will develop sooner or later depending on the temperature. As mentioned, time is also an important factor, and it is highly dependent on $\mathrm{a}_{\mathrm{w}}$, temperature and substrate characteristics [24]. Several models have been developed indicating potential risks of mould growth by predicting the time of different mould development stages. Usually, the tests predicting mould growth are obtained for a situation where the wood specimens prior to the tests are sprayed with water suspensions of a mixture of spore monocultures in relatively high concentrations [14,15,31-33]. Such approach would predict the worst-case scenario; however, indoors, it is relatively unrealistic. In addition, the spraying of the spore suspension changes the moisture content near the surface, which can accelerate the mould growth [16]. These aspects have had minor attention in the literature.

Nevertheless, the prediction of mould growth is challenging and still more research should be done for efficient prevention. The objective of the present study was to investigate the effect of less studied factors as initial moisture content of wood and spore contamination on mould development indoors.

\section{Materials and Methods}

Scots pine (Pinus sylvestris L.) was used as a wood substrate in all experiments. Kilndried rift-sawn boards composed solely of sapwood and measuring $3000 \times 100 \times 25 \mathrm{~mm}$ were sourced from a local sawmill. Seven boards were used to prepare test specimens measuring $110 \times 40 \times 10 \mathrm{~mm}$ (EN 152). During the specimen preparation, all the original surfaces of the boards were removed by planning to ensure that the exposed surfaces were free of extra nutrients resulting from the migration of the extractives to the surface due to kiln-drying $[34,35]$. One specimen from each board was allocated to each test ensuring similar sets of wood substrate for all experiments. Consequently, 7 replica specimens were used for each test. After preparing, all specimens were conditioned in a constant temperature $\left(20 \pm 1{ }^{\circ} \mathrm{C}\right)$ and $\mathrm{RH}(50 \pm 3 \%)$ environment. The specimens conditioned in this way without any further treatment are referred to as 'Dry' through the paper.

Four experiments were carried out. In the Experiment I, mould development on the 'Dry' specimens depending on temperature and RH was evaluated. In the Experiment II, accidental wetting of wood was simulated by immersing the specimens in water for 30 min followed by blotting off the excess of water. These specimens are referred to as 'Wet'. In the Experiment I and Experiment II, the only source of mould was spores normally present on wood and in the air ('clean' conditions). In the Experiment III, 'Dry' specimens were exposed to environments with and without extra source of mould contamination. The specimens exposed to environment with a contaminator are referred to as 'With contaminator'. In the Experiment IV, influence of the moisture content of wood at the 
moment, when conditions favourable for mould growth are provided, was evaluated. The specimens were conditioned until a constant weight in a container of the definite $\mathrm{RH}$ equipped with a vessel containing toluene for preventing mould growth. No direct contact between wood and toluene was ensured. In such a way, the specimens had reached equilibrium moisture content (EMC) for the definite $\mathrm{RH}$ before they were inserted into the test chamber. These specimens are referred to as 'At EMC'. The experiment IV was carried out in an environment with a source of mould contamination.

Simulations of six constant environmental conditions were included in the experiments, which were formed by a combination of two RH (91\% and 97\%) and three temperatures $\left(10,20\right.$ and $\left.30^{\circ} \mathrm{C}\right)$. Saturated salt solutions were used to maintain definite $\mathrm{RH}$ of an environment in sealed containers during a test. The salts used were: $\mathrm{BaCl}_{2}$ for $\mathrm{RH} 91 \%$ at $10{ }^{\circ} \mathrm{C}$ and at $20{ }^{\circ} \mathrm{C}$ and $\mathrm{KNO}_{3}$ for $30{ }^{\circ} \mathrm{C} ; \mathrm{K}_{2} \mathrm{SO}_{4}$ was used for $\mathrm{RH}$ of $97 \%$ for all tested temperatures. Desiccators were used as the containers. During the test, the containers were kept in climate chambers to maintain the required temperature (Figure 1a). To monitor the climate during tests, the containers were equipped with wireless thermo-hygrometers (TFA Dostmann GmbH \& Co. KG) transmitting the results to a receiver. For evaluating the effect of presence of a contaminated wood material on development of mould (Experiment III and Experiment IV), the chambers were equipped with an elevated stage on which a mould-infected piece of wood was mounted (Figure 1b). The infected wood was obtained by exposure of pine sapwood to high $\mathrm{RH}(97 \%)$ until more than $50 \%$ of the specimen was covered by visually detectable mould (Figure 1c).
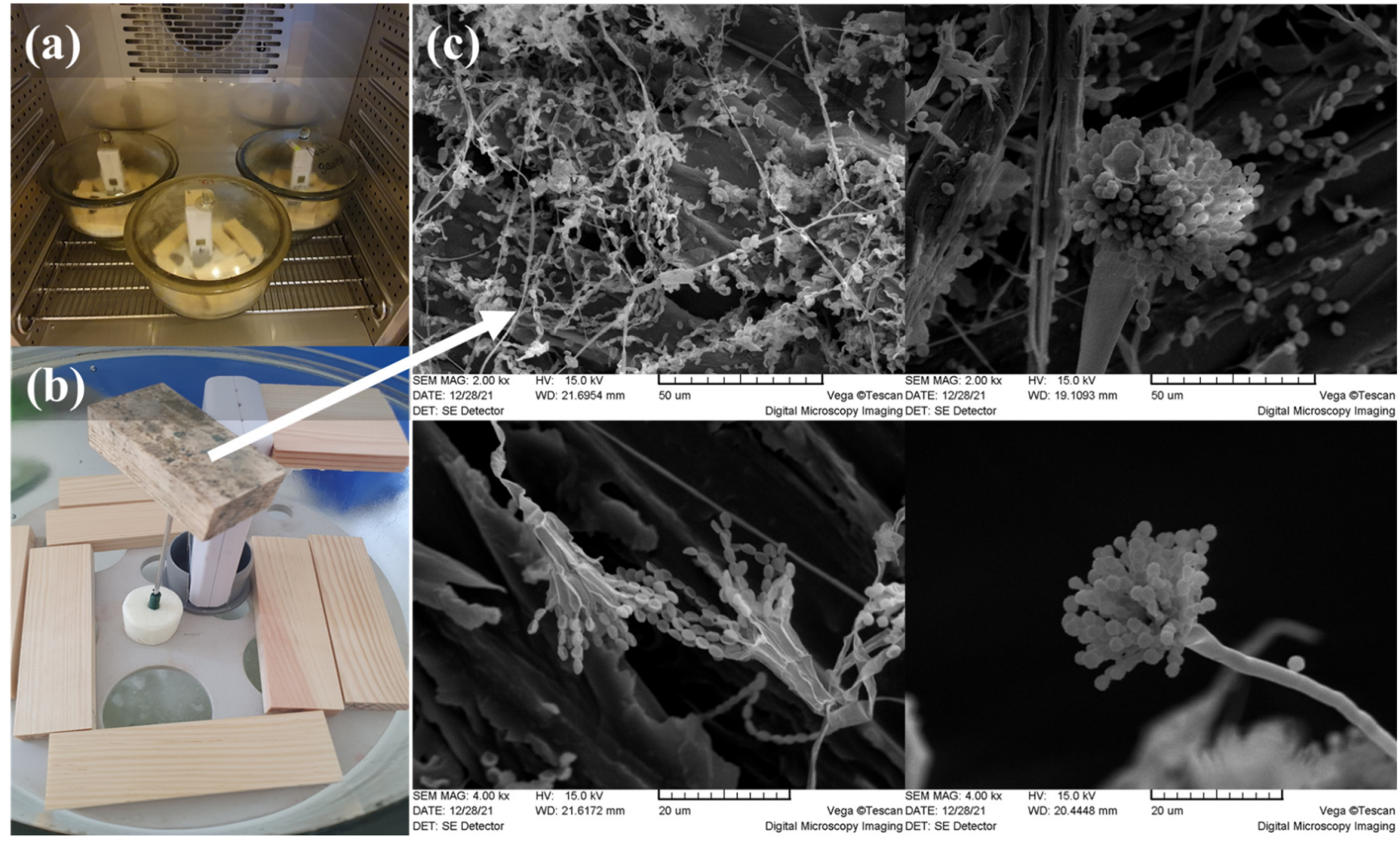

Figure 1. Illustration of the experiments: (a) test containers in a climate chamber; (b) setup of the test with mould-infected wood (experiments III and IV); (c) SEM images of the mould-infected wood specimen.

The specimens were regularly withdrawn from the containers to assess the mould growth. The examination of specimens to detect germination of mould growth was carried out by microscopic inspection of surface using optical microscope ZEISS Stemi 508 fitted with a LED ring light at $40 \times$ magnification. The average time (days) needed to reach mould 
germination and visible mould growth was calculated for each test from seven replicate specimens. The specimen was withdrawn from the test chamber after visible mould growth was detected.

All specimens were weighed prior to inserting them into the test chamber and periodically during the test. The dry weight of the specimens for calculating the moisture content $(M C)$ was determined at the end of the test (after visible mould growth was detected) by drying the specimens at $103^{\circ} \mathrm{C}$ until constant mass. $M C$ was calculated according to the equation:

$$
M C=\frac{m-m_{0}}{m_{0}} \times 100, \%
$$

$m$-mass of wet specimen, $\mathrm{g}$

$m_{0}$ - mass of oven dry specimen, $\mathrm{g}$

The error bars presented in the graphs are standard deviations. The differences in the mean values were compared by using analysis of variance (ANOVA) with a $5 \%$ significance level $(\alpha=0.05)$.

\section{Results and Discussion}

\subsection{Effect of Constant RH and Temperature on Mould Growth Development at 'Clean' Conditions (Experiment I)}

Moulds are present nearly anywhere [13]. Therefore, objects are exposed to spores also indoors regardless of any locally noticeable mould contamination. At certain conditions, spores can germinate causing mould growth. The investigation of the effect of $\mathrm{RH}$ and temperature at such 'clean' conditions has been rarely reported due to ambiguity caused by unknown variety and number of spores in the air, which can influence reproducibility [36]. However, the situation without artificial mould inoculation is more natural and possibly can even provide a more reliable estimate of the period required for the mould development indoors. In the study, a scenario of sudden change in $\mathrm{RH}$ and temperature to values, which are favourable to mould growth, is investigated for 'clean' indoor conditions. The results are compared with the widely used VTT model developed by Hukka and Viitanen as a reference [24]. The obtained results presented in Figure 2 show the days necessary to reach mould germination (Figure 2a) and visible mould growth (Figure 2b) on wood specimens depending on different ambient air conditions for both situations (experiment I and calculation of VTT model).
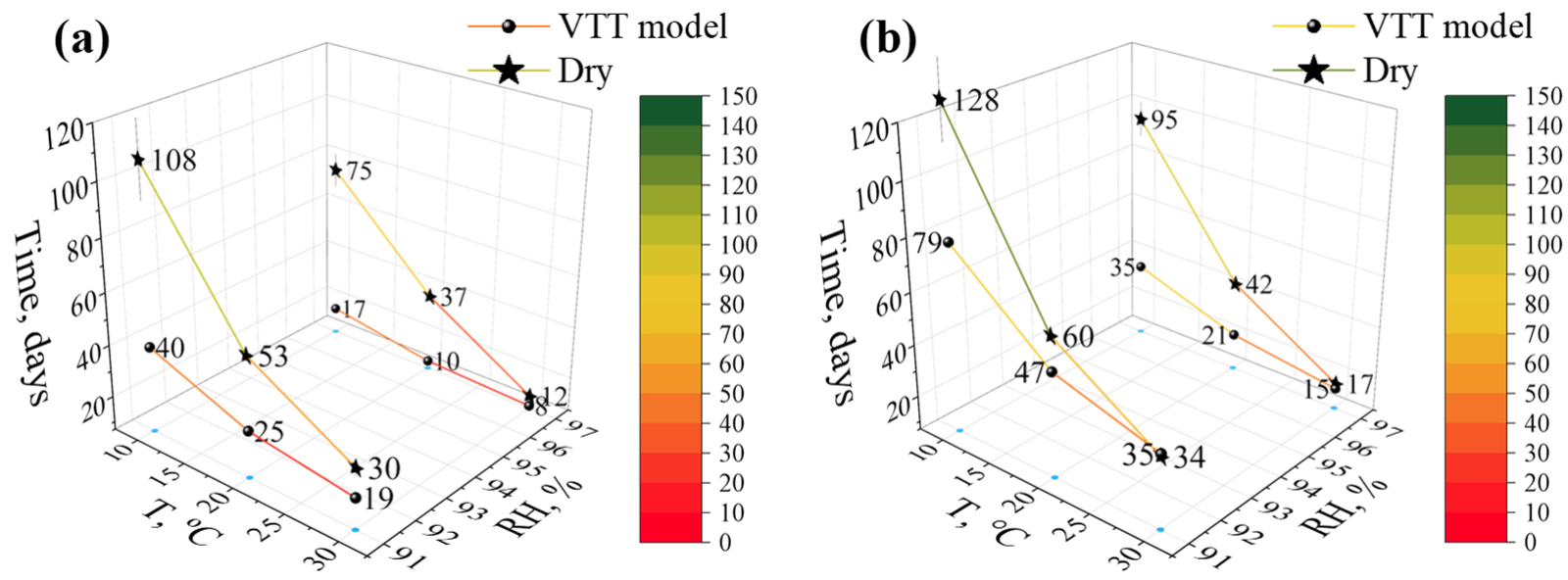

Figure 2. Effect of temperature $\left(10,20\right.$ and $\left.30{ }^{\circ} \mathrm{C}\right)$ and $\mathrm{RH}(91 \%$ and $97 \%)$ on the time necessary to reach (a) mould germination and (b) visible mould growth stages in the experiment I ('Dry') and calculated according to the VTT model [24]; light blue dots on the T and RH plane are the corresponding projections of the results. 
The results show that both $\mathrm{RH}$ and temperature are important factors, which significantly influence the rate of mould growth. By decreasing temperature and $\mathrm{RH}$, a longer period is necessary for mould to develop. This agrees with the overall knowledge [30]. The results showing the difference between 'clean' conditions and the prediction of the VTT model are quite interesting. At lower temperature, the difference is large; however, at higher temperature, it is relatively small or even insignificant. At $10{ }^{\circ} \mathrm{C}$, it takes on average 108 days at $\mathrm{RH} 91 \%$ and 75 days at $\mathrm{RH} \mathrm{97 \% ,} \mathrm{to} \mathrm{reach} \mathrm{the} \mathrm{mould} \mathrm{germination} \mathrm{stage} \mathrm{in} \mathrm{the}$ case of the 'clean' conditions, which is 2.7 and 4.4 times longer than it is predicted by the VTT model. Concerning the stage of visible mould growth, the difference is smaller; however, still significant: 1.6 (at RH 91\%) and 2.7 (at RH 97\%) times longer period is necessary at the 'clean' conditions. In contrast, for the highest temperature $\left(30^{\circ} \mathrm{C}\right)$, the differences between the 'clean' conditions and the VTT model in most cases are insignificant, except for the mould germination at $\mathrm{RH} 91 \%$. This indicates that in the case of higher temperatures $\left(30{ }^{\circ} \mathrm{C}\right)$, the spores present in the air can develop on the wood as effective as the ones which are inoculated onto the wood surface in a relatively large amount prior to the test. This could be explained by the increase in the probability of the spore germination, which at optimal conditions can be close to $100 \%$; therefore, the effect of spore concentration is becoming less decisive [37]. Furthermore, the results suggest that the initial spore concentration (spores in the ambient air versus spore suspension of high concentration) for lower temperatures $\left(10\right.$ and $20^{\circ} \mathrm{C}$ ) has a significant influence only on the mould germination stage. Further mould development up to visible mould growth is more influenced by other factors. In addition, the results show that the period form mould germination to visible mould growth is even shorter in the case of 'clean' conditions. These results could be explained by the potential reciprocal influence of the mould fungi among each other, which can interfere with the mould development in the case of mixed mould monocultures [38]. Further discussion of the subject will be continued in Section 3.3.

\subsection{Effect of Accidental Wetting of Wood on the Mould Growth Development at 'Clean' Conditions (Experiment II)}

Wood as a hygroscopic material readily absorbs water when comes in contact with liquid water unless the surface is protected by coating. Liquid water penetration into wood is a complex process governed mainly by capillary forces and diffusion $[39,40]$. The amount of the absorbed water depends mainly on the contact time and the rate of the water absorption, which depends on a number of factors such as principal direction of the surface, wood species, density, anatomical structure including peculiarities of intercellular connections and ratio of bordered pit aspiration, etc. [41-50]. On the other hand, desorption is a reversed process, which starts immediately in an environment with $\mathrm{RH}<100 \%$. Desorption rate depends mainly on the environmental conditions ( $\mathrm{RH}$ and temperature), and the rate of evaporation is the limiting factor of the process [51,52]. It is well established that absorption and desorption isotherms do not follow the same curve resulting in sorption hysteresis with dissimilar EMC for equal environment ( $\mathrm{RH}$ and temperature) [53]. Changes in wood MC of 'Dry' and 'Wet' specimens after placing them into the sealed mould test containers with the corresponding $\mathrm{RH}$ and temperature are presented in Figure 3.

The mass of specimens increased by $25 \pm 5 \%$ on average due to water absorption during immersion. However, the moisture content (MC) gradient is formed with high MC levels next to the surface and steep decrease in the direction away from the surface $[40,41,44,46,47]$. Therefore, the MC determined for a wetted wood material provides only information about the average $\mathrm{MC}$, which may greatly differ from the MC of the surface layer before the EMC is reached. It can be seen that the EMC for both tested $\mathrm{RH}$ levels was considerably higher for 'Wet' specimens (circles) than 'Dry' specimens (triangles). An exception was the environment of $\mathrm{RH} 91 \%$ and temperature $30{ }^{\circ} \mathrm{C}$, when the difference between the EMC of 'Dry' and 'Wet' specimens was only $0.5 \%$. In addition, higher EMC was detected for the 'Wet' specimens when drying took place at lower temperature, especially in the case of $\mathrm{RH} 91 \%$, when the difference between EMC of the 
'Wet' specimens held at $10{ }^{\circ} \mathrm{C}$ and $30{ }^{\circ} \mathrm{C}$ was more than $6 \%$. No difference in EMC was observe between the 'Dry' specimens depending on temperature. This agrees with the finding that changes in temperature do not affect adsorption isotherm while desorption isotherm for higher temperatures is moved to the right resulting in lower EMC for a given constant RH [53,54]. Generally, the main consequence of the wood wetting was higher EMC compared with 'Dry' specimens under similar conditions. However, considerable effect of the wood wetting on the mould growth was only observed for the specimens exposed to the lowest tested temperature $\left(10^{\circ} \mathrm{C}\right)$, when significantly higher rate of mould germination as well visible mould growth was detected for the 'Wet' specimens (Figure 4). For other conditions, no differences in the mould development were observed between the 'Dry' and 'Wet' specimens suggesting that accidental wetting of wood does not affect mould development at these conditions. This agrees with the finding of Johansson et al. (2012) that mould growth rate on pine sapwood is considerably more influenced by $\mathrm{RH}$ at a temperature of $10{ }^{\circ} \mathrm{C}$ compared with $22{ }^{\circ} \mathrm{C}$ [55].

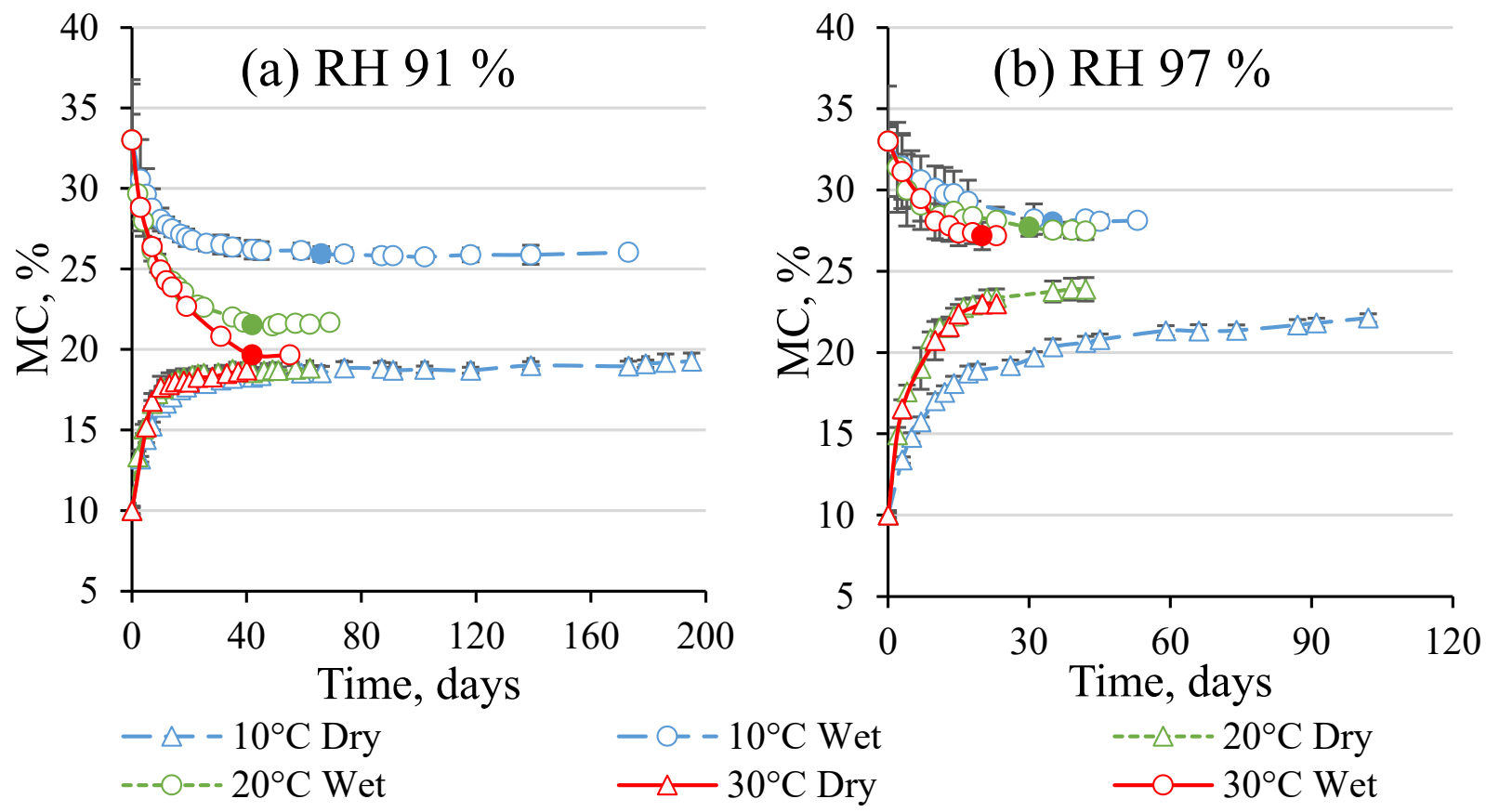

Figure 3. Changes in moisture content (MC) of 'Dry' and 'Wet' specimens exposed to constant conditions: temperature $\left(10,20\right.$ and $30^{\circ} \mathrm{C}$ ) and humidity (a) RH 91\% and (b) RH 97\%.

Wood drying includes two interrelated processes that may have certain effect on the environment nearby the surface. Evaporation of water is an endothermic process causing decrease in temperature, on the one hand. The difference of $0.6-1.0{ }^{\circ} \mathrm{C}$ in surface temperature between 'Dry' and 'Wet' specimens was found by measuring the surface temperature with an infrared thermometer during the initial stage of the test of similar conditions (results not presented). On the other hand, evaporation results in higher ambient $\mathrm{RH}$ next to the surface. According to the psychrometric chart, the increase in RH, which corresponds to detected decrease in temperature, may be up to $6 \%$ for the tested air humidity levels. Increased RH next to the surface due to evaporation is as long as the EMC is reached. As it can be seen from the Figure 3, considerably less time is needed to reach the EMC (filled circles) at temperatures $20^{\circ} \mathrm{C}$ and $30^{\circ} \mathrm{C}$ compared to temperature $10{ }^{\circ} \mathrm{C}$. Consequently, for these specimens, higher RH next to the surface was for less time. The relatively faster reaching of the EMC could be the reason why no difference in mould development was observed between 'Dry' and 'Wet' specimens at temperatures of $20{ }^{\circ} \mathrm{C}$ and $30^{\circ} \mathrm{C}$. 

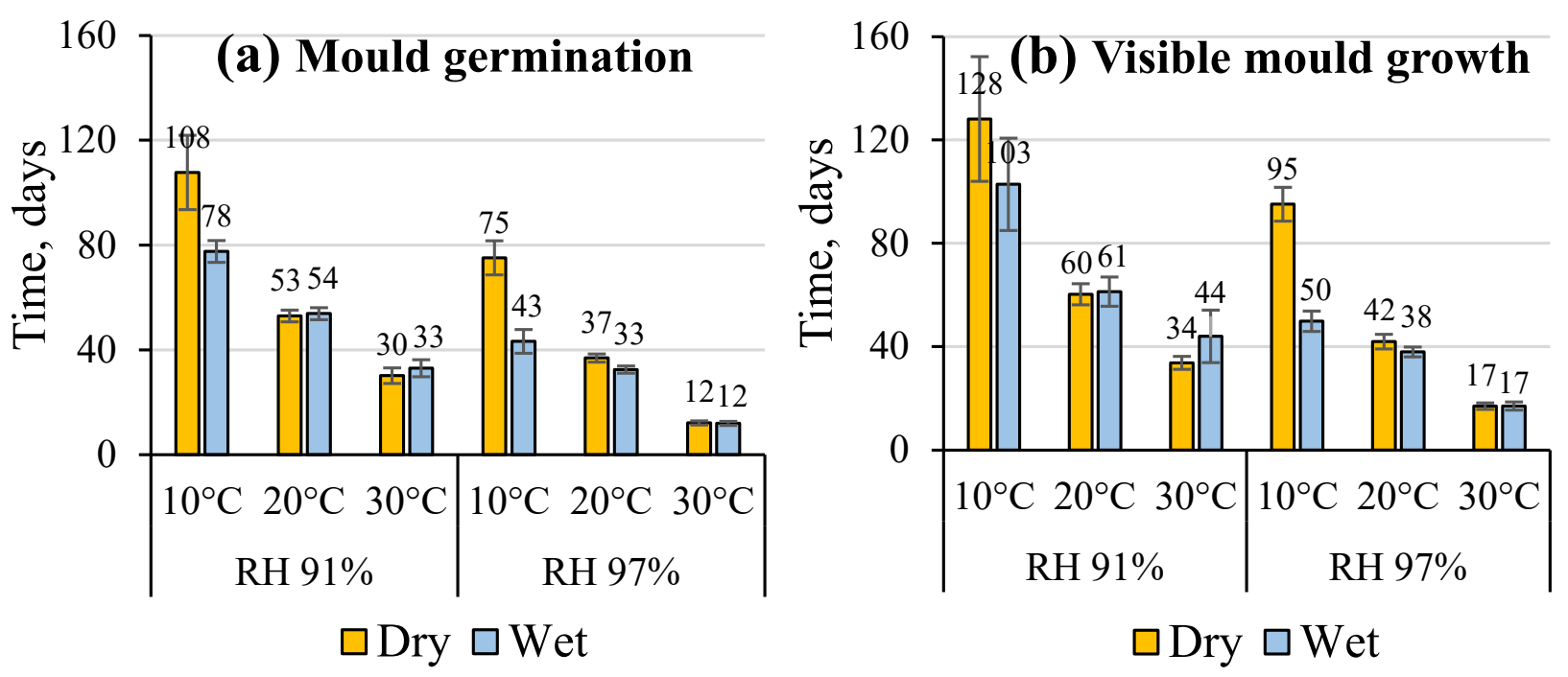

Figure 4. Time needed to reach definite mould growth stage for 'Dry' and 'Wet' specimens at different conditions: (a) mould germination and (b) visible mould growth.

\subsection{Effect of Accidental Wetting of Wood on the Mould Growth Development at 'Clean' Conditions (Experiment II)}

In the Section 3.1, the mould growth in the case of 'clean' conditions was analysed and compared with the VTT model, which is based on the experiments using mould spore contaminated wood specimens (sprayed with a spore mixture of mould monocultures). The main differences between these methods are that for the 'clean' conditions, the initial spore concentration is relatively low, and the test is more realistic compared to the VTT model. Introduction of mould-infected objects into the 'clean' conditions before the test is a method that ensures higher mould spore concentration in the test environment. Due to poor reproducibility, such approach has similar restrictions as for the 'clean' conditions. However, it is a more realistic simulation of mould spore contamination indoors compared to the test involving spraying of mould spore suspension. The use of mould-infected wood specimen has been analysed by Ahmed et al. (2013) with the objective of obtaining a more rapid mould testing method [36]. The results of their study showed that the method was very reliable for modelling mould infestation at natural conditions, suggesting that the results are even more precise than in the case of other standard test methods. A scenario of a mould-infected object introduced into a 'clean' room is quite realistic because mould can be present on some object without being noticed, and only detailed inspection would identify it [56]. The results showing the effect of different initial mould contamination conditions on the mould development are presented in Figure 5.

Regarding the mould germination (Figure 5a), the presence of the spore contaminator in most cases has a significant effect on this process except for the most favourable conditions for mould growth (RH $97 \%$ and temperature $30^{\circ} \mathrm{C}$ ) where no significant difference is observed. The 'Dry (with contaminator)' specimens, which were exposed to mould-infected object, show similar results to the ones predicted by the VTT model. The least favourable conditions ( $\mathrm{RH} 91 \%$ and temperature $20^{\circ} \mathrm{C}$ ) are the only exception when a slightly longer period is necessary to reach the mould germination stage for 'Dry (with contaminator)' specimens. These results indicate that the VTT model can relatively accurately predict the mould germination of a scenario when the wood is exposed to conditions with mouldinfected objects. This indicates that the amount of spores are sufficient and can germinate as efficiently regardless of the contamination source (mould-infected object or mixed spore suspension) in the tested environmental conditions. Concerning visible mould growth (Figure 5b) the prediction by the VTT model and the results of the 'Dry (with contaminator)' specimens are also relatively similar, especially in the case of RH 97\%. For RH 91\%, visible mould growth appears few days sooner on the 'Dry (with contaminator)' specimens. This, 
as mentioned above, could be due to competition between different mould species in the case of the VTT model, which inhibits mould development [38]. The results of the 'Dry' specimens are similar to the ones exposed to the mould contamination at $30^{\circ} \mathrm{C}$. However, they are completely different at $20^{\circ} \mathrm{C}$, suggesting that initial spore concentration is very important under these conditions.
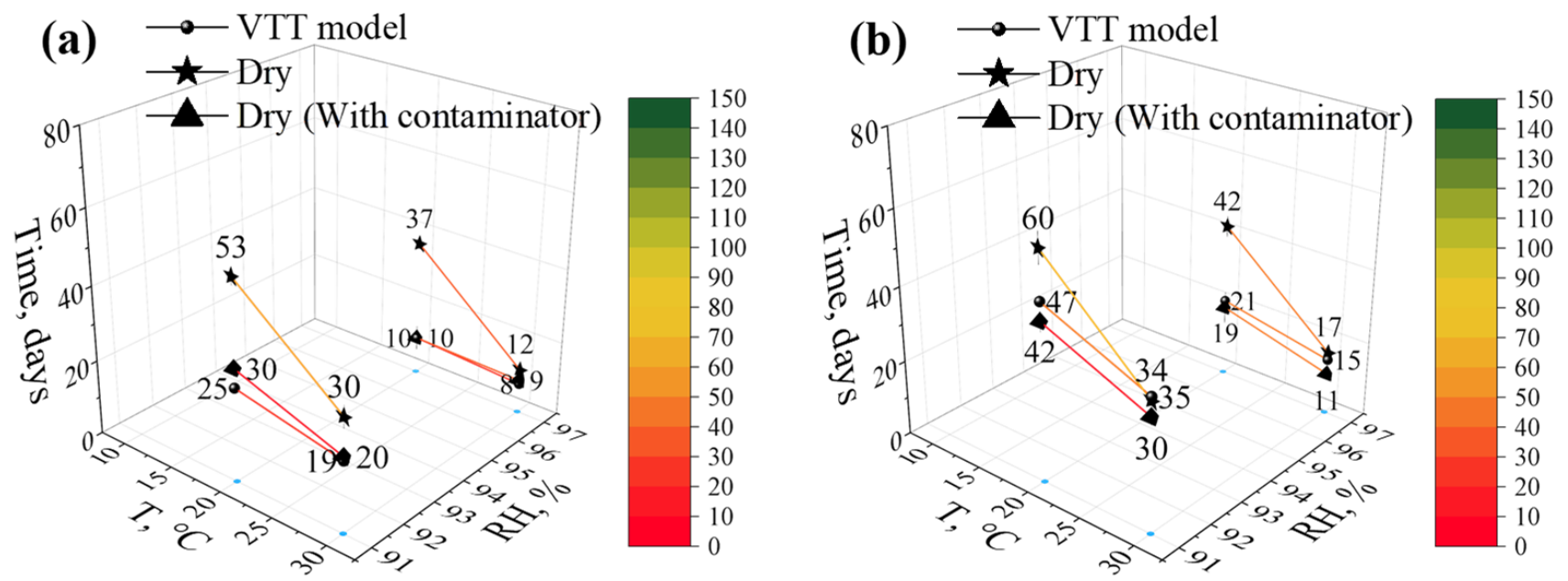

Figure 5. Influence of mould contamination on the time necessary reach (a) mould germination and (b) visible mould growth stages; 'Dry' —no contamination, 'Dry (with contaminator)' —with mould-infected object, VTT model—prediction by VTT model (spore suspension) [24]; light blue dots on the $\mathrm{T}$ and $\mathrm{RH}$ plane are the corresponding projections of the results.

Taking into consideration that the detection of mould growth in the early development stages can be difficult, and therefore, it is not always known if the indoor air is actually 'clean' from the spore contaminators [56], the results suggest that the VTT model is safe and reliable for mould prediction on wood. The results of other frequently used methods (Sedlbauer isopleths, WUFI-Bio model, etc.), which are summarised in the paper by Vereecken and Roels (2012), differ considerably from the presented results [57]. At RH 97\% and temperature $20{ }^{\circ} \mathrm{C}$, most of these models predict much sooner mould germination ( $\sim 5$ to 10 times) than we have observed in our experiments. On the other hand, WUFI-Bio model predicts longer period ( 2 times), which is more comparable to the results of the 'clean' conditions. In general, much more research would be required to ascertain which one of the models is more reliable. However, based on our experiments and the covered environmental conditions, a relatively precise and safe model that could potentially be used for development of indicative warning system for potential risk of mould growth at extreme situations (RH $>90 \%$ and temperature $>20^{\circ} \mathrm{C}$ ) indoors for wood is the VTT model.

\subsection{Effect of the MC of Wood on Mould Growth Development Exposed to Environment with Mould Contaminator (Experiment IV)}

The effect of the MC of wood on mould development was evaluated in the experiment in which 'Dry' and 'At EMC' specimens were exposed to an environment favourable for mould growth. A significant difference was observed for the 'At EMC' rate, reaching EMC between the RH of the environment while no effect of temperature was detected. Although there were significantly greater changes in MC for the 'Dry' specimens exposed to an environment of RH 97\% than for their counterparts at RH 91\% (increases of $15 \%$ and $10 \%$, respectively), similar time was needed for them to reach EMC (Figure 6). This agrees with the finding that the rate of absorption for a smaller RH increment was slower than for a larger RH increment [58]. 

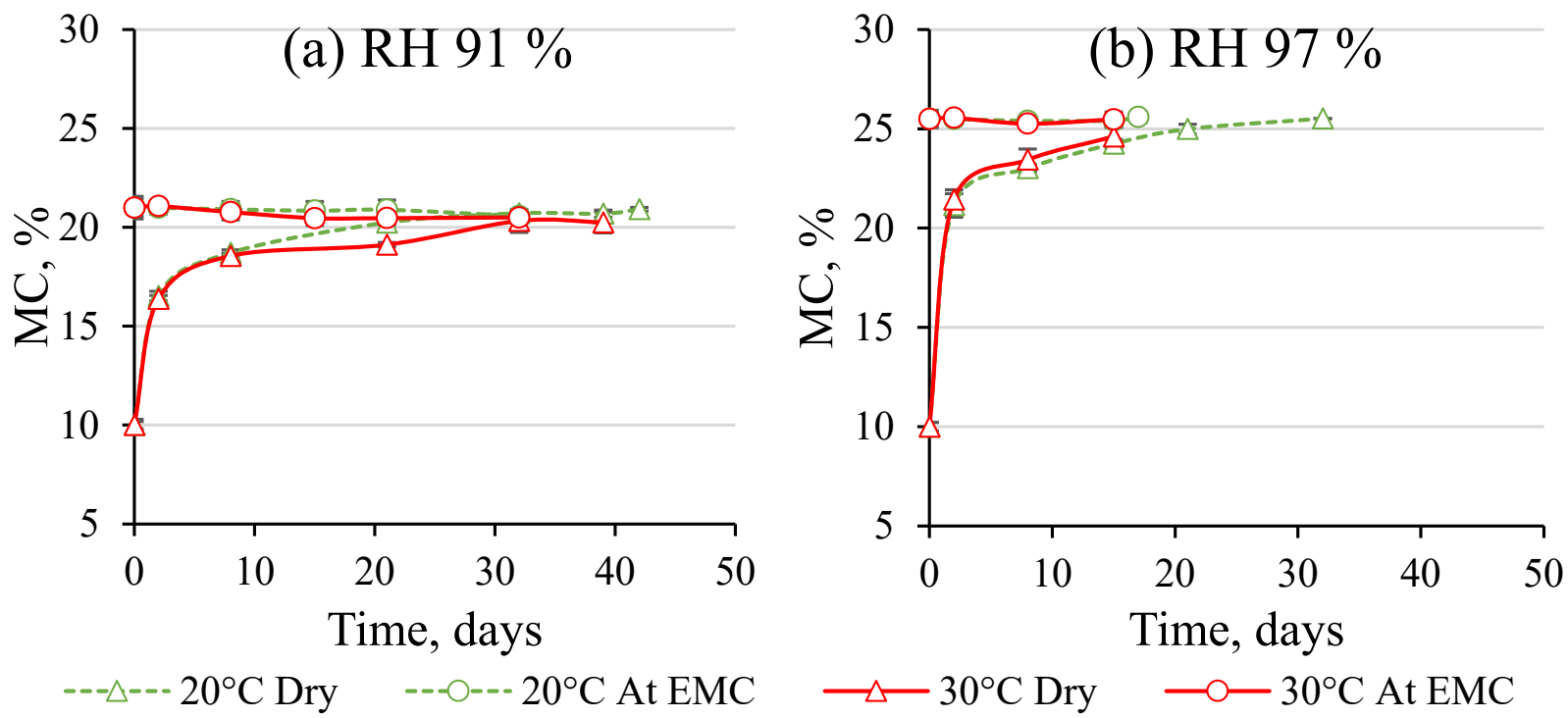

Figure 6. Changes in moisture content (MC) of 'Dry' (prior the test conditioned at RH 50\%) and 'At $\mathrm{EMC}^{\prime}$ (prior the test conditioned at 91 or $97 \%$ ) specimens exposed to constant conditions: temperature $\left(20^{\circ} \mathrm{C}\right.$ and $30^{\circ} \mathrm{C}$ ) and humidity (a) RH 91\% and (b) RH 97\%.

Some effect of wood MC on mould development was only observed for the specimens exposed to an environment of RH $91 \%$ and a temperature $20{ }^{\circ} \mathrm{C}$ when significantly less time was needed for mould germination on the 'At EMC' specimens (Figure 7). These specimens were detected reaching the visible mould growth stage more rapidly compared with their 'Dry' counterparts. However, the difference in the time to reach visible mould growth between the 'Dry' and 'At EMC' specimens was not significant $(p>0.05)$ for any of the environmental conditions. These results suggest that the wood MC is not of significant importance for mould development, at least under the studied conditions of high RH. The findings agree with the other studies $[15,16]$.
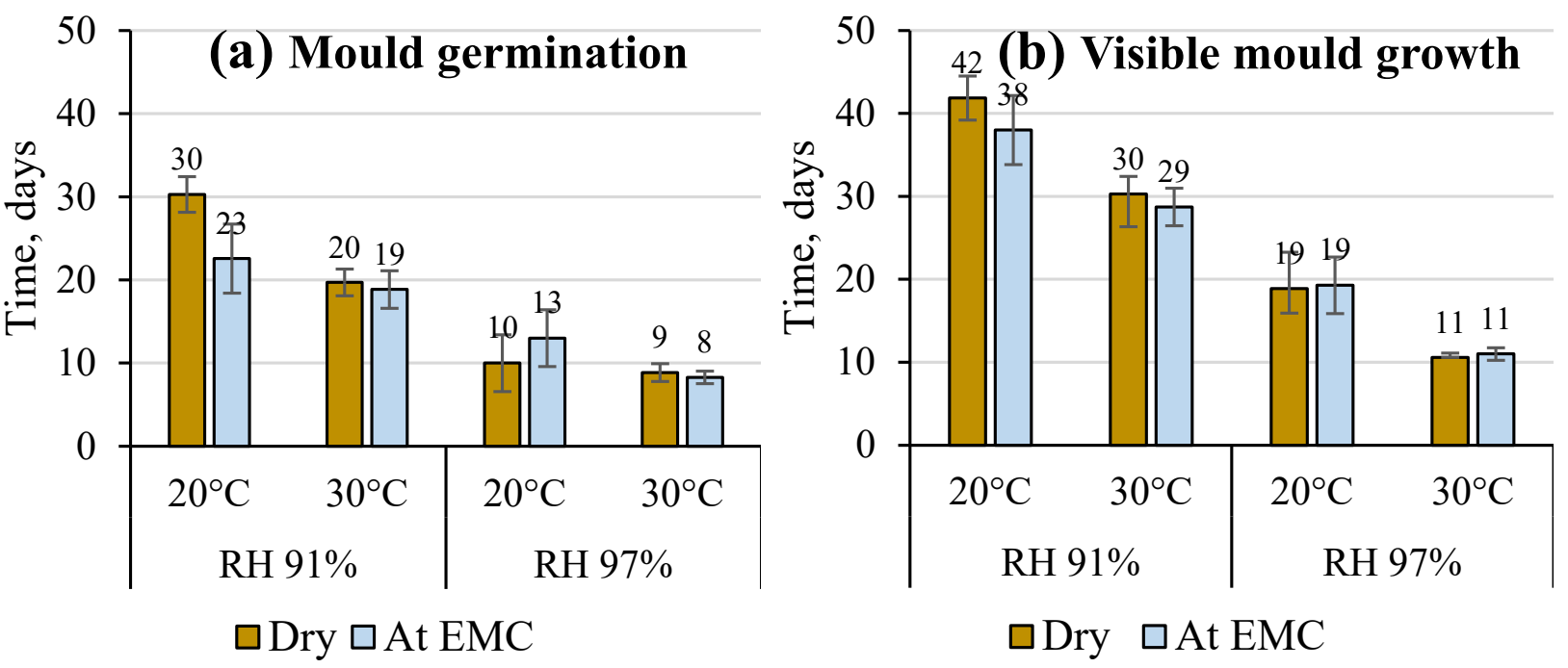

Figure 7. Time needed to reach the definite mould growth stage for 'Dry' (prior test conditioned at RH 50\%) and 'At EMC' (prior test conditioned at RH 91 or 97\%) specimens at different conditions; (a) mould germination and (b) visible mould growth. 


\section{Conclusions}

The effects of wood moisture content and spore contamination on mould growth have been investigated by carrying out mould tests at different conditions. The following conclusions can be drawn from the present study:

- The rate of mould growth is considerably affected by the presence of spore contamination at the temperatures of 10 and $20{ }^{\circ} \mathrm{C}$ for both $\mathrm{RH}(91 \%$ and $97 \%)$; however, a relatively small or even insignificant difference was observed at a temperature of $30^{\circ} \mathrm{C}$.

- The VTT model can predict mould growth with relatively good accuracy when wood is exposed to conditions of mould-infected objects.

- No significant difference was detected in mould growth development between 'Dry' and 'Wet' wood specimens exposed to 'clean' conditions at temperatures of 20 and $30{ }^{\circ} \mathrm{C}$ for both $\mathrm{RH}(91 \%$ and $97 \%)$, while a significantly higher rate of mould growth was observed for the 'Wet' specimens at a temperature of $10^{\circ} \mathrm{C}$.

- No significant difference was detected in mould growth development between 'Dry' and 'At EMC' specimens exposed to a mould-infected object at a temperature of $30^{\circ} \mathrm{C}$ for both $\mathrm{RH}\left(91 \%\right.$ and $97 \%$ ) and at $20^{\circ} \mathrm{C}$ for $\mathrm{RH} 97 \%$. The rate of mould growth is significantly higher for the 'At EMC' than for the 'Dry' specimens at a temperature of $20{ }^{\circ} \mathrm{C}$ for $\mathrm{RH} 91 \%$.

Author Contributions: Conceptualization, I.A. and D.C.; methodology, I.A. and D.C.; formal analysis, E.K. and D.C.; investigation, V.F.; resources, B.A.; data curation, E.K.; writing-original draft preparation, E.K., D.C. and I.A.; writing-review and editing, E.K., D.C. and I.A.; visualization, E.K. and V.F.; supervision, B.A.; funding acquisition, B.A. All authors have read and agreed to the published version of the manuscript.

Funding: This project has received funding from the European Union's Horizon 2020 research and innovation programme under grant agreement No. 814624.

Informed Consent Statement: Not applicable.

Acknowledgments: The authors are grateful for the support from the H2020 project "Innovative and affordable service for the Preventive Conservation monitoring of individual Cultural Artefacts during display, storage, handling and transport (CollectionCare)".

Conflicts of Interest: The authors declare no conflict of interest.

\section{References}

1. Gradeci, K.; Labonnote, N.; Time, B.; Köhler, J. Mould growth criteria and design avoidance approaches in wood-based materials-A systematic review. Constr. Build. Mater. 2017, 150, 77-88. [CrossRef]

2. Heseltine, E.; Rosen, J. WHO Guidelines for Indoor Air Quality: Dampness and Mould; World Health Organization: Copenhagen, Denmark, 2009.

3. Nielsen, K.F.; Holm, G.; Uttrup, L.; Nielsen, P. Mould growth on building materials under low water activities. Influence of humidity and temperature on fungal growth and secondary metabolism. Int. Biodeterior. Biodegrad. 2004, 54, 325-336. [CrossRef]

4. Hunter, C.; Grant, C.; Flannigan, B.; Bravery, A. Mould in buildings: The air spora of domestic dwellings. Int. Biodeterior. 1988, 24, 81-101. [CrossRef]

5. Pasanen, A.-L.; Juutinen, T.; Jantunen, M.; Kalliokoski, P. Occurrence and moisture requirements of microbial growth in building materials. Int. Biodeterior. Biodegrad. 1992, 30, 273-283. [CrossRef]

6. Andersen, B.; Frisvad, J.C.; Søndergaard, I.; Rasmussen, I.S.; Larsen, L.S. Associations between fungal species and wa-ter-damaged building materials. Appl. Environ. Microbiol. 2011, 77, 4180-4188. [CrossRef] [PubMed]

7. Tsongas, G.A.; Rioroan, F. Minimum conditions for visible mold growth. ASHRAE J. 2016, 58, 32-43.

8. Nielsen, K.F. Mycotoxin production by indoor molds. Fungal Genet. Biol. 2003, 39, 103-117. [CrossRef]

9. Guild, S.; MacDonald, M. Mould Prevention and Collection Recovery: Guidelines for Heritage Collections-Technical Bulletin 26; Canadian Conservation Institute: Ottawa, ON, Canada, 2004.

10. Sterflinger, K. Fungi: Their role in deterioration of cultural heritage. Fungal Biol. Rev. 2010, 24, 47-55. [CrossRef]

11. Kim, M.-J.; Choi, Y.-S.; Oh, J.-J.; Kim, G.-H. Experimental investigation of the humidity effect on wood discoloration by selected mold and stain fungi for a proper conservation of wooden cultural heritages. J. Wood Sci. 2020, 66, 1-5. [CrossRef]

12. Broda, M. Natural Compounds for Wood Protection against Fungi-A Review. Molecules 2020, 25, 3538. [CrossRef] 
13. Adan, O.C.G.; Samson, R.A. Fundamentals of Mold Growth in Indoor Environments and Strategies for Healthy Living; Wageningen Academic Publishers: Wageningen, The Netherlands, 2011.

14. Feng, J.; Li, C.; Chen, J.; Chen, M.; Shu, X.; Shi, Q. Evaluation of the association between natural mold resistance and chemical components of nine wood species. BioResources 2019, 13, 6524-6541. [CrossRef]

15. Arango, R.; Yang, V.; Lebow, S.; Lebow, P.; Wiemann, M.; Grejczyk, M.; DeWald, P. Variation in mold susceptibility among hardwood species under laboratory conditions. Int. Biodeterior. Biodegrad. 2020, 154, 105082. [CrossRef]

16. Brischke, C.; Alfredsen, G. Wood-water relationships and their role for wood susceptibility to fungal decay. Appl. Microbiol. Biotechnol. 2020, 104, 3781-3795. [CrossRef] [PubMed]

17. Taylor, A.M.; Gartner, B.L.; Morrell, J.J. Heartwood formation and natural durability-A review. Wood Fiber Sci. 2002, 34, 587-611.

18. Gobakken, L.R.; Westin, M. Surface mould growth on five modified wood substrates coated with three different coating systems when exposed outdoors. Int. Biodeterior. Biodegrad. 2008, 62, 397-402. [CrossRef]

19. Imken, A.A.P.; Brischke, C.; Kögel, S.; Krause, K.C.; Mai, C. Resistance of different wood-based materials against mould fungi: A comparison of methods. Eur. J. Wood Wood Prod. 2020, 78, 661-671. [CrossRef]

20. Yinodotlgör, N.; Kartal, S.N. Heat Modification of Wood: Chemical Properties and Resistance to Mold and Decay Fungi. For. Prod. J. 2010, 60, 357-361. [CrossRef]

21. Kamperidou, V. The Biological Durability of Thermally- and Chemically-Modified Black Pine and Poplar Wood Against Basidiomycetes and Mold Action. Forests 2019, 10, 1111. [CrossRef]

22. Andersone, I.; Dobele, G.; Andersons, B.; Kurnosova, N.; Kuka, E.; Volperts, A.; Grinins, J. A study of thermo-hydro-treated (THT) birch wood by chemical analysis and Py-GC/MS. Holzforschung 2019, 73, 653-661. [CrossRef]

23. Hens, H. IEA Annex 14: Condensation and Energy. J. Therm. Insul. 1992, 15, 261-273. [CrossRef]

24. Hukka, A.; Viitanen, H.A. A mathematical model of mould growth on wooden material. Wood Sci. Technol. 1999, 33, 475-485. [CrossRef]

25. Lie, S.K.; Vestøl, G.I.; Høibø, O.; Gobakken, L.R. Surface mould growth on wood: A comparison of laboratory screening tests and outdoor performance. Holz als Roh- und Werkst. 2019, 77, 1137-1150. [CrossRef]

26. Anagnost, S. Wood in the built environment-conditions for mold and decay. In Sampling and Analysis of Indoor Microorganisms; Yang, C.S., Heinsohn, P.A., Eds.; John Wiley \& Sons, Inc.: Hoboken, NJ, USA, 2007; pp. 155-178.

27. Ferdyn-Grygierek, J.; Kaczmarczyk, J.; Blaszczok, M.; Lubina, P.; Koper, P.; Bulińska, A. Hygrothermal Risk in Museum Buildings Located in Moderate Climate. Energies 2020, 13, 344. [CrossRef]

28. Martens, M.H.J. Climate risk assessment in museums: Degradation risks determined from temperature and relative humidity data. Build. Environ. 2012, 2005, 41-44.

29. Sharif-Askari, H.; Abu-Hijleh, B. Review of museums' indoor environment conditions studies and guidelines and their impact on the museums' artifacts and energy consumption. Build. Environ. 2018, 143, 186-195. [CrossRef]

30. Ayerst, G. The effects of moisture and temperature on growth and spore germination in some fungi. J. Stored Prod. Res. 1969, 5, 127-141. [CrossRef]

31. Viitanen, H.A. Modelling the Time Factor in the Development of Mould Fungi-The Effect of Critical Humidity and Temperature Conditions on Pine and Spruce Sapwood. Holzforschung 1997, 51, 6-14. [CrossRef]

32. Sedlbauer, K. Prediction of Mould Fungus Formation on the Surface of/and inside Building Components. Ph.D. Thesis, Universität Stuttgart, Stuttgart, Germany, 2001.

33. Møller, E.B.; Andersen, B.; Rode, C.; Peuhkuri, R. Conditions for mould growth on typical interior surfaces. Energy Procedia 2017, 132, 171-176. [CrossRef]

34. Johansson, P.; Wamming, T.; Bok, G.; Edlund, M.-L. Mould growth on kiln-dried and air-dried timber. Eur. J. Wood Wood Prod. 2013, 71, 473-481. [CrossRef]

35. Myronycheva, O.; Sidorova, E.; Hagman, O.; Sehlstedt-Persson, M.; Karlsson, O.; Sandberg, D. Hyperspectral Imaging Surface Analysis for Dried and Thermally Modified Wood: An Exploratory Study. J. Spectrosc. 2018, 2018, 7423501. [CrossRef]

36. Ahmed, S.A.; Sehlstedt-Persson, M.; Morén, T. Development of a new rapid method for mould testing in a climate chamber: Preliminary tests. Eur. J. Wood Wood Prod. 2013, 71, 451-461. [CrossRef]

37. Doran, W.L. Effect of External and Internal Factors on the Germination of Fungous Spores. Bull. Torrey Bot. Club 1922, $49,313$. [CrossRef]

38. Northolt, M.D.; Bullerman, L.B. Prevention of Mold Growth and Toxin Production through Control of Environmental Condi-tions. J. Food Prot. 1982, 45, 519-526. [CrossRef]

39. Banks, W.B. Water uptake by scots pine sapwood, and its restriction by the use of water repellents. Wood Sci. Technol. 1973, 7, 271-284. [CrossRef]

40. Sandberg, K.; Salin, J.-G. Liquid water absorption in dried Norway spruce timber measured with CT scanning and viewed as a percolation process. Wood Sci. Technol. 2012, 46, 207-219. [CrossRef]

41. Fakhouri, B.; Mounji, H.; Vergnaud, J.M. Comparison of the absorption and desorption of water betweenscots pine and spruce after submersion in water. Holzforschung 1993, 47, 271-277. [CrossRef]

42. de Meijer, M.; Militz, H. Moisture transport in coated wood. Part 1: Analysis of sorption rates and moisture content profiles in spruce during liquid water uptake. Holz als Roh- und Werkst. 2000, 58, 354-362. [CrossRef]

43. Metsä-Kortelainen, S.; Antikainen, T.; Viitaniemi, P. The water absorption of sapwood and heartwood of Scots pine and Norway spruce heat-treated at $170{ }^{\circ} \mathrm{C}, 190^{\circ} \mathrm{C}, 210^{\circ} \mathrm{C}$ and $230^{\circ} \mathrm{C}$. Holz als Roh- und Werkst. 2006, 64, 192-197. [CrossRef] 
44. Salin, J.-G. Modelling water absorption in wood. Wood Mater. Sci. Eng. 2008, 3, 102-108. [CrossRef]

45. Ahmed, S.A.; Chun, S.K.; Miller, R.B.; Chong, S.H.; Kim, A.J. Liquid penetration in different cells of two hardwood species. J. Wood Sci. 2011, 57, 179-188. [CrossRef]

46. Sedighi-Gilani, M.; Griffa, M.; Mannes, D.; Lehmann, E.; Carmeliet, J.; Derome, D. Visualization and quantification of liquid water transport in softwood by means of neutron radiography. Int. J. Heat Mass Transf. 2012, 55, 6211-6221. [CrossRef]

47. Gezici-Koç, Ö.; Erich, S.J.F.; Huinink, H.P.; Van Der Ven, L.G.J.; Adan, O.C.G. Bound and free water distribution in wood during water uptake and drying as measured by $1 \mathrm{D}$ magnetic resonance imaging. Cellulose 2017, 24, 535-553. [CrossRef]

48. Antons, A.; Cirule, D.; Verovkins, A.; Kuka, E. Effect of thermal treatment on physical and mechanical properties of birch and pine wood. In Proceedings of the Research for Rural Development, 24th Annual International Scientific Conference on Research for Rural Development, Jelgava, Latvia, 16-18 May 2018; pp. 78-85. [CrossRef]

49. Cirule, D.; Verovkins, A.; Andersone, I.; Kuka, E.; Andersons, B. Thermally modified birch wood interaction with liquids. Holzals Roh- und Werkst. 2020, 78, 1-9. [CrossRef]

50. Kuka, E.; Andersons, B.; Cirule, D.; Andersone, I.; Kajaks, J.; Militz, H.; Bicke, S. Weathering properties of wood-plastic composites based on heat-treated wood and polypropylene. Compos. Part. A Appl. Sci. Manuf. 2020, 139, 106102. [CrossRef]

51. El Kouali, M.; Bouzon, J.; Vergnaud, J.M. Process of absorption and desorption of water in a wood board, with 3-dimensional transport beyond the FSP. Wood Sci. Technol. 1992, 26, 307-321. [CrossRef]

52. Li, X.; Wang, X.; Zhang, M. An Investigation of the Drying Rate of Water in Wood at Different Relative Humidities Studied by Time Domain Nuclear Magnetic Resonance. Bioresour. 2017, 12, 2991-3000. [CrossRef]

53. Engelund, E.T.; Thygesen, L.G.; Svensson, S.; Hill, C.A.S. A critical discussion of the physics of wood-water interactions. Wood Sci. Technol. 2013, 47, 141-161. [CrossRef]

54. Hill, C.A.S.; Norton, A.J.; Newman, G. The water vapour sorption properties of Sitka spruce determined using a dynamic vapour sorption apparatus. Wood Sci. Technol. 2010, 44, 497-514. [CrossRef]

55. Johansson, P.; Ekstrand-Tobin, A.; Svensson, T.; Bok, G. Laboratory study to determine the critical moisture level for mould growth on building materials. Int. Biodeterior. Biodegrad. 2012, 73, 23-32. [CrossRef]

56. Suchorab, Z.; Frąc, M.; Guz, Ł.; Oszust, K.; Łagód, G.; Gryta, A.; Bilińska-Wielgus, N.; Czerwiński, J. A method for early de-tection and identification of fungal contamination of building materials using e-nose. PLoS ONE 2019, 14, 1-17. [CrossRef]

57. Vereecken, E.; Vanoirbeek, K.; Roels, S. Towards a more thoughtful use of mould prediction models: A critical view on experimental mould growth research. J. Build. Phys. 2015, 39, 102-123. [CrossRef]

58. Thybring, E.E.; Glass, S.V.; Zelinka, S.L. Kinetics of water vapor sorption in wood cell walls: State of the art and research needs. Forests 2019, 10, 704. [CrossRef] 